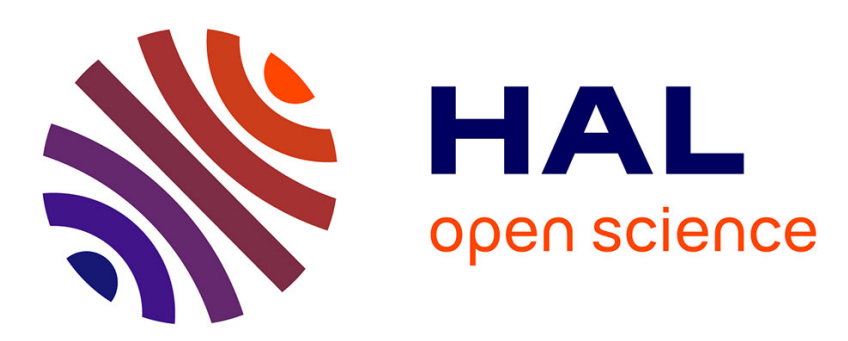

\title{
Pulsed light effects on surface decontamination, physical qualities and nutritional composition of tomato fruit
} Ingrid Aguiló-Aguayo, Florence Charles, Catherine M.G.C. Renard, David Page, Frederic Carlin

\section{- To cite this version:}

Ingrid Aguiló-Aguayo, Florence Charles, Catherine M.G.C. Renard, David Page, Frederic Carlin. Pulsed light effects on surface decontamination, physical qualities and nutritional composition of tomato fruit. Postharvest Biology and Technology, 2013, 86, pp.29-36. 10.1016/j.postharvbio.2013.06.011 . hal-01332317

\section{HAL Id: hal-01332317 https://hal.science/hal-01332317}

Submitted on 29 May 2020

HAL is a multi-disciplinary open access archive for the deposit and dissemination of scientific research documents, whether they are published or not. The documents may come from teaching and research institutions in France or abroad, or from public or private research centers.
L'archive ouverte pluridisciplinaire HAL, est destinée au dépôt et à la diffusion de documents scientifiques de niveau recherche, publiés ou non, émanant des établissements d'enseignement et de recherche français ou étrangers, des laboratoires publics ou privés. 


\title{
Pulsed light effects on surface decontamination, physical qualities and nutritional composition of tomato fruit
}

\author{
Ingrid Aguiló-Aguayo ${ }^{\mathrm{a}, *}$, Florence Charles ${ }^{\mathrm{b}}$, Catherine M.G.C. Renard ${ }^{\mathrm{c}, \mathrm{d}}$, David Page ${ }^{\mathrm{c}, \mathrm{d}}$, \\ Frederic Carlin ${ }^{\mathrm{c}, \mathrm{d}}$ \\ a Department of Food Technology, University of Lleida - Agrotecnio Center, Av. Alcalde Rovira Roure 191, 25198 Lleida, Spain \\ b Université d'Avignon et des Pays de Vaucluse, Laboratoire Physiologie des Fruits et Légumes (EA 4279), F-84018 Avignon, France \\ ' INRA, UMR408 Sécurité et Qualité des Produits d'Origine Végétale, F-84000 Avignon, France \\ d Université d'Avignon et des Pays de Vaucluse, UMR408 Sécurité et Qualité des Produits d'Origine Végétale, F-84000 Avignon, France
}

Keywords:

Pulsed light

Surface decontamination

Nutritional quality

Tomato

\begin{abstract}
A B S T R A C T
Pulsed light (PL) is a nonthermal food technology with a potential as postharvest decontamination strategy for fruit and vegetables. The feasibility of PL in extending shelf-life of food products while assuring appropriate quality is still under investigation. The effect of pulsed light (PL) on surface decontamination (natural and inoculated microorganisms), physical (colour, texture and weight) and nutritional quality (ascorbic acid and major carotenoids) was investigated in red-ripe tomatoes during 15 days of storage at $20^{\circ} \mathrm{C}$. The application of PL treatments at fluences of 2.68 and $5.36 \mathrm{~J} / \mathrm{cm}^{2}$ reduced microbial loads during storage of whole tomatoes. One $\log _{10}$ reduction on the microflora present in both skin and peduncle scar parts of the tomato was obtained with a fluence of $4 \mathrm{~J} / \mathrm{cm}^{2}$. Fluences of $2.2 \mathrm{~J} / \mathrm{cm}^{2}$ allowed a $2.3 \log _{10}$ reduction of Saccharomyces cerevisiae inoculated onto the tomato surface. Softening, increased loss of weight, and wrinkles on the tomato surface appeared after 3 days on PL treated tomato fruit. Ascorbic acid levels remained unchanged during storage. Total lycopene, $\alpha$-carotene and $\beta$-carotene contents and lycopene isomerisation percent were higher in tomato extracts prepared with fresh tomato fruit treated with a high PL dose of $30 \mathrm{~J} / \mathrm{cm}^{2}$. An increase in the bio-accessibility of lycopene was observed in hot-break purees prepared with fresh tomatoes treated at $5.36 \mathrm{~J} / \mathrm{cm}^{2}$ and stored 15 days. In conclusion, PL treatment of fresh tomato would result in a reduction in microbiological contaminants without compromising the nutritional value; but it did induce some appearance defects.
\end{abstract}

\section{Introduction}

Tomatoes are widely consumed throughout the world and are considered an important source of dietary antioxidants due to their content in carotenoids, vitamins and phenolic compounds (Giovanelli et al., 1999). Lycopene and $\beta$-carotene are the main carotenoids responsible of tomato colour, which influence quality perception. High processing temperature, prolonged processing time, and light or oxygen exposure may favour tomato pigment degradation and lower nutritional value (Heredia et al., 2009). Carotenoids have received considerable attention because of their possible role in the prevention of chronic diseases such as prostate cancer (Clinton, 1998; Rao and Agarwal, 2000).

Senescence, transpiration and postharvest disease development limit the storage life of fresh tomato (Charles et al., 2008). Postharvest treatment of tomato with ultraviolet (UV)-C radiation (peak emission at $254 \mathrm{~nm}$ ) provided by fluorescent germicidal lamps

\footnotetext{
* Corresponding author. Tel.: +34 973702593.

E-mail address: iaguilo@tecal.udl.cat (I. Aguiló-Aguayo).
}

delays fungal growth or senescence (Maharaj et al., 1999; Ait Barka et al., 2000), increases ascorbic acid, total phenolic and lycopene content in tomato fruit (Jagadeesh and Jagadeesh, 2009; Liu et al., 2009). Pulsed light (PL) is a nonthermal technology that has received recent attention for postharvest decontamination of fruit and vegetables, including tomato (Kalaras et al., 2012; Luksiene et al., 2012). PL consists of pulses of intense light generated by Xenon lamps (Wekhof, 2000). The pulses present a continuous spectrum (200-1100 nm wavelengths) rich in UV that last a few hundred of microseconds. The mechanism of microbial inactivation by PL has been explained through the photochemical effect inducing structural changes in DNA of bacteria, viruses, and other pathogens, thus preventing the cell from replicating (Takeshita et al., 2003). The antimicrobial action of PL against microorganisms also involved the agglutination of the cytoplasmatic content, leading to a disruption of cell membranes (Ramos-Villarroel et al., 2012). Thus, significant and rapid microbial inactivation in short-time treatments, lack of residual compounds and great flexibility are some of the advantages of this technology for food application (Elmnasser et al., 2007). 
Version définitive du manuscrit publiée dans / Final version of the manuscript published in :

Postharvest Biology and Technology (2013), Vol. 86, p. 29-36, DOI: 10.1016/j.postharvbio.2013.06.011

Journal homepage: www.elsevier.com/locate/postharvbio

The most crucial challenge of PL processing is to optimise treatment conditions to extend shelf-life of food products, while assuring appropriate quality. For instance, PL application on minimally processed apple slices at a dose of $11.9 \mathrm{~J} / \mathrm{cm}^{2}$ could extend shelf-life with minimal modification in colour (Gómez et al., 2012). A similar dose is effective in reducing Escherichia coli and Listeria innocua growth of fresh-cut avocado and watermelon, but also caused browning and softening (Ramos-Villarroel et al., 2011, 2012).

The present research examines the effect of PL on microbial contaminants (native microflora and a spiked micro-organism common on fruit surfaces, Saccharomyces cerevisiae), physical characteristics (colour, firmness and fruit weight) as well as nutritional composition (ascorbic acid, carotenoid contents, biodegradation and bioavailability) in tomato during 15 days of storage at $20^{\circ} \mathrm{C}$.

\section{Materials and methods}

\subsection{Plant material preparation}

Red ripe tomatoes (Lycopersicum esculentum L. type "bunch", var Climberley) harvested at maturity between March and May in Entressens (South-East of France) were used for the experiment. The weight of the tested tomatoes was (mean $\pm S D$ ) $144 \pm 11 \mathrm{~g}$ and colour parameters at reception to the laboratory were $L^{*}=37.0 \pm 0.7 ; \quad a^{*}=20.3 \pm 0.6 ; \quad b^{*}=19.1 \pm 0.4$. Experiments were conducted with whole tomatoes or several fractions depending on the study objective.

\subsubsection{Tomato portions}

Disc of pericarp of $6.25 \mathrm{~cm}^{2}$ with a thickness of approx. $1 \mathrm{~cm}$ and weighing approx. $5 \mathrm{~g}$ were cut with a pastry-cutter through the epidermis and including the pericarp tissues. Gels and the columella section that came with the disc were discarded. These tomato portions were used for the microbiological tests.

\subsubsection{Tomato tissue isolation}

Red ripe tomatoes were cut into quarters following transverse and longitudinal sections of the fruit. The seeds and the gel and columella were eliminated and the pericarp was cut into disks of $2 \mathrm{~cm}$ diameter and $0.5 \mathrm{~cm}$ thickness. These tomato plugs were used to study the nutritional composition in tomato tissue.

\subsubsection{Chromoplast isolation}

To isolate chromoplasts, approximately $300 \mathrm{~g}$ of tomatoes plugs were ground for $30 \mathrm{~s}$ using a Waring ${ }^{\circledR}$ blender (bowl: $1 \mathrm{~L}$ ). The ground tomatoes were rinsed with an isotonic buffer containing Hepes $(0.25 \mathrm{M})$ and sorbitol (330 mM) (Sigma-Aldrich) and filtered through four sieves with decreasing mesh sizes of $1 \mathrm{~mm}, 250 \mu \mathrm{m}$, $125 \mu \mathrm{m}$ and $60 \mu \mathrm{m}$. The material retained on the $60 \mu \mathrm{m}$ sieve was then centrifuged at $8000 \times g$ for $10 \mathrm{~min}$. The resulting sediment contained the tomato chromoplasts.

\subsubsection{Raw and hot break purees from whole tomatoes}

Raw and hot break purees from whole untreated and PL-treated tomatoes were prepared for conducting lycopene extraction. For raw purees, entire tomatoes were cut in large pieces, ground for 30 s into a Waring ${ }^{\circledR}$ blender (bowl: $1 \mathrm{~L}$ ) and immediately used for oil diffusion and lycopene measurement.

For hot break purees, three to four tomatoes (around $250 \mathrm{~g}$ ) were packed in a sealed plastic bag perforated to avoid over pressure. Bag was heated $\left(0.35 \mathrm{~s} \mathrm{~g}^{-1}\right.$ of tomato $)$ using a domestic microwave oven at $900 \mathrm{~W}$, left the same duration in the turned-off oven to allow the homogenisation of the temperature of the fruit and finally heated once again for the same duration. The bag was then quickly cooled to room temperature by immersion in cold water and then tomatoes were ground for $30 \mathrm{~s}$ in a Waring ${ }^{\circledR}$ blender (bowl: $1 \mathrm{~L}$ ) and immediately used for oil diffusion and lycopene measurement. This procedure has been optimised to simulate the hot break treatments usually used in tomato industry.

\subsection{Pulsed light treatments}

A commercial automatic PL unit (CLARANOR S.A., Avignon, France) equipped with eight automatic flash xenon lamps situated all around the sample holder was used to process whole tomatoes. Whole tomatoes were treated with 1 and 2 pulses by delivering a fluence of $2.68 \mathrm{~J} / \mathrm{cm}^{2}$ per pulse under a charging voltage of $2.5 \mathrm{kV}$. These samples were stored for 15 days at $20^{\circ} \mathrm{C}$.

Tomato portions (epidermis and penduncle scar), tissue and chromoplast were processed by a Lab-scale PL unit (CLARANOR SA, Avignon, France) equipped by three flash xenon lamps situated above the sample holder. Treatments consisted of a number of pulses ranging from 1 to 30 with a fluence of $1 \mathrm{~J} / \mathrm{cm}^{2}$ per pulse under a charging voltage of $2.5 \mathrm{kV}$. Variations in fluences in the Lab-scale PL unit were obtained in changing the distance between the light source and the samples. Fluences were measured using a joulemeter Gentec QE $12 \mathrm{LP}$, with a $1.1 \mathrm{~cm}$ edge square probe connected to a SOLO 2 Power and Energy meter (Gentec Electro-Optics Inc., Quebec, Canada).

Xenon flash lamps of both PL units produced short-time pulses of $250 \mu \mathrm{s}$ and of broad spectrum (200-1100 nm) white light with approx. $18 \%$ of UV (225-385 nm) under a charging voltage of $2.5 \mathrm{kV}$. Temperature measurements were performed in all the samples using a noncontact, type K infrared thermometer (Fisher Scientific). Immediately after the PL treatment, the samples were taken out of the PL unit and tilted to an angle of about $30^{\circ}$. Temperature was recorded by placing the head of the thermometer at a distance of $15 \mathrm{~cm}$ from the surface of the sample. The time elapsed between the cessation of the PL treatment and the temperature measurement was about $3 \mathrm{~s}$.

\subsection{Analytical procedures}

\subsubsection{Microbiological analysis}

2.3.1.1. Counts of aerobic mesophilic bacteria, yeast and mould populations. Total counts of aerobic mesophilic bacteria, yeast and mould populations were determined during 15 days of storage of PL-treated whole tomatoes. The counts were performed in five tomato portions of $5 \mathrm{~g}$ extracted from the epidermis of five whole tomatoes corresponding at each corresponding PL condition.

Total aerobic mesophilic counts were carried out in PLprocessed $5 \mathrm{~g}$ tomato portions taken from the epidermis and peduncle scar of each fruit. Total counts of these tomato portions were carried out three times in each corresponding PL condition and the whole experiment was independently conducted three times.

Homogenisation of tomato portions in $20 \mathrm{~mL}$ of $0.1 \%$ sterile peptone water was performed with a Stomacher ${ }^{\circledR}$ (Merck Eurolab, Strasbourg, France) at full speed for one min. Serial dilutions of the homogenates were poured in Luria Bertani (LB) agar at $30^{\circ} \mathrm{C}$ for $24 \mathrm{~h}$ for mesophilic aerobic bacteria counts and in chloramphenicol potato dextrose agar (PDB $+20 \mathrm{~g} / \mathrm{L}$ of agar $+0.5 \mathrm{~g} / \mathrm{L}$ chloramphenicol) at $25^{\circ} \mathrm{C}$ for 5 days for yeast and mould counts.

2.3.1.2. S. cerevisiae inoculation and enumeration. To prepare inoculum, a $S$. cerevisiae strain culture grown on potato dextrose agar (PDB $+20 \mathrm{~g} / \mathrm{L}$ of agar), for $48 \mathrm{~h}$ at $30^{\circ} \mathrm{C}$ was inoculated into $10 \mathrm{~mL}$ of potato dextrose broth (PDB) and incubated for $48^{\circ} \mathrm{C}$ at $30^{\circ} \mathrm{C}$ with gentle shaking. After incubation, the cell suspension was harvested after centrifugation $(8000 \times g ; 10 \mathrm{~min})$, washed twice in a 
Version définitive du manuscrit publiée dans / Final version of the manuscript published in :

Postharvest Biology and Technology (2013), Vol. 86, p. 29-36, DOI: 10.1016/j.postharvbio.2013.06.011

Journal homepage: www.elsevier.com/locate/postharvbio

sterile saline solution $(0.9 \% \mathrm{NaCl}, \mathrm{w} / \mathrm{v})$ and suspended again at the appropriate concentration in the same solution.

Tomato portions of $5 \mathrm{~g}$ taken from the epidermis were inoculated with a drop of $10 \mu \mathrm{L}$ of $S$. cerevisiae suspension containing approximately $1 \times 10^{5} \mathrm{CFU}$. The area of the tomato portion was $6.25 \mathrm{~cm}^{2}$ and the drop covered around $0.8 \mathrm{~cm}^{2}$. The deposited suspension was kept for $30 \mathrm{~min}$ under a laminar flow cabinet for $30 \mathrm{~min}$ to allow surface drying while minimising yeast death. Tomato portions were subjected to PL processing. Three portions of tomato in each PL condition were inoculated and the same experiment was independently conducted three times. Non-inoculated tomato portions incubated under the same conditions as inoculated tomatoes were used as control untreated samples.

Treated tomato samples $(5 \mathrm{~g}$ ) were mixed to in $20 \mathrm{~mL}$ of phosphate buffer (0.1 M, pH 6.8) and homogenised with a Stomacher ${ }^{\circledR}$ (Merk Eurolab, Strasbourg, France) at full speed for one min. A volume of $200 \mu \mathrm{L}$ of appropriate dilutions in phosphate buffer of the tomato homogenate was spread on PDB agar plates. The plates were then incubated at room temperature during $24 \mathrm{~h}$ before colony counting. The microbial reduction was expressed as $\log _{10}\left(N_{0} / N\right)$, where $N_{0}$ was the initial concentration of the spotted and dried microbial suspension and $\mathrm{N}$ the number of surviving cells, as a function of the applied fluence.

\subsubsection{Physical characteristics of the fruit}

Physical characteristics of eight fruit pieces including weight, firmness and colour measurements were evaluated throughout storage and three readings were obtained from each piece. Moreover, tomato fruit were observed during storage for development of moulds, and visible loss of turgescence such as wrinkled skin.

The changes of weight during the storage of untreated and PLtreated whole tomatoes were expressed as relative loss of weight (Eq. (1)).

Relative loss of weight $=\frac{W_{t}}{W_{0}}$

where $W_{t}$ is the weight of each PL-treated sample at each sampling time and $W_{\mathrm{o}}$ is the weight of untreated sample at the beginning of storage, respectively.

2.3.2.1. Tomato firmness. Firmness was evaluated as the force necessary to obtain a deformation corresponding to $3 \%$ of the fruit diameter (Grotte et al., 2001) and was assessed with a texturometer (Texture analyser TAplus; Ametek, Lloyd Instruments Ltd., Fareham, UK). This apparatus registered force/deformation curves by measuring the reaction force in response to an increasing mechanical constraint applied to the fruit by a $5 \mathrm{~cm}$ flat disc supported by a motorised arm. The probe speed was $300 \mathrm{~mm} / \mathrm{min}$. Results were expressed as relative loss of firmness corresponded to the Eq. (2):

Relative loss of firmness $=\frac{F_{t}}{F_{0}}$

where $F_{t}$ is the firmness of each PL-treated sample at each sampling time and $F_{\mathrm{O}}$ is the firmness of untreated sample at the beginning of storage, respectively.

2.3.2.2. Colour measurements. The colour of tomatoes was determined with a Minolta CR-400 Chroma meter (Konica Minolta Sensing, Inc., Osaka, Japan), equipped with a $\mathrm{D}_{75}$ light source and the observer at $10^{\circ}$. The CIE colour parameters: $L^{*}$ (lightness), $a^{*}$ (red-green) and $b^{*}$ (yellow-blue) were measured. Hue angle $\left(h^{\circ}\right)$ was calculated using the following Eq. (3):

$h^{\circ}=\tan ^{-1} \frac{b *}{a *}$

\subsubsection{Chemical analysis}

2.3.3.1. Chemicals. Methanol for chromatography was HPLC grade and obtained from VWR international (Fontenay-sousbois, France), as were extraction solvents (ethyl acetate, dichloromethane, hexan). Lycopene was obtained from Extrasynthese (Genay, France). Amonium acetate, $\beta$-apo8'carotenal and $\beta$-carotene were obtained from Sigma-Aldrich (Deisenhofen, Germany).

2.3.3.2. Carotenoid extraction and quantification. Carotenoid extraction was carried out using the micromethod described by Page et al. (2012), including the addition of $\beta$-apo8'carotenal used as internal standard. The extract was analysis by HPLC equipped with diode array detector (SPD-M20A Shimadzu inc., Kyoto, Japan). Column used was C30 $(250 \mathrm{~mm} \times 4.6 \mathrm{~mm}$, particle size $3 \mu \mathrm{m}$, YMC Co, Kyoto, Japan). The temperature of column oven was $30^{\circ} \mathrm{C}$, flow rate $1.4 \mathrm{~mL} \mathrm{~min}^{-1}$, injection volume $20 \mu \mathrm{L}$. The mobile phase was methanol and the polarity gradient was achieved with MTBE, starting with $100 \%$ methanol, and increasing to $60 \%$ MTBE in $20 \mathrm{~min}$, remaining isocratic during $5 \mathrm{~min}$, then back to $100 \%$ methanol in 5 min and finally $100 \%$ methanol for 10 more minutes. Compounds were detected at wavelength from $280 \mathrm{~nm}$ to $600 \mathrm{~nm}$, and quantified at $450 \mathrm{~nm}$ (for apo-carotenal, $\beta$ carotene and $503 \mathrm{~nm}$ (for lycopene, and iso-lycopene). $\beta$-Carotene, $E$-lycopene and $\beta$-apo8'carotenal were identified by co-elution of standards. The others, and especially $\alpha$-carotene and $Z$-lycopene isomers, were tentatively identified according to their UV spectrum and quantified as equivalent of E-lycopene. Quantification was performed relative to the peak area of the internal standard ( $\beta$-apo8'carotenal). Response factors were calculated for lycopene and $\beta$-carotene from standards solutions. Percentage of isomerisation of the lycopene was calculated by pooling the peak surface of all the putative $Z$ isomers.

2.3.3.3. Carotenoid diffusion. Bio-accessibility of oil was mimicked through a simple diffusion of the lycopene contained in the tomato puree to an oil phase following the method described by Degrou et al. (2013).

2.3.3.4. Determination of ascorbic acid contents. Measurements of reduced and oxidised ascorbic acid contents were carried out following the method described by Stevens et al. (2008). Transverse sections from the middle of the fruit were frozen and ground to a fine powder in liquid nitrogen, and were stored at $-80^{\circ} \mathrm{C}$ prior to ascorbic acid content assay.

\subsection{Statistical analysis}

Two repetitions of the whole experiment were carried out and each analysis was performed at least in triplicate. The mean values and standard deviations were calculated from data obtained using means from the three analytical determinations. Moreover, since it can be assumed that the two series of the experiment were of the same precision although their means differed, the corresponding pooled standard deviations were also calculated (McNaught and Wilkinson, 1997).

The significant difference between samples was analysed by means of one-way ANOVA and Student's $t$-test. The threshold $p$ value chosen for statistical significance was $p<0.05$. Differences among treatments $(p<0.05)$ throughout the storage time were evaluated using an analysis of covariance (ANCOVA). The Duncan method was used to determine differences between means. All statistical analyses were performed using Statgraphics Plus v.5.1 Windows package (Statistical Graphics Co., Rockville, MD). 
Version définitive du manuscrit publiée dans / Final version of the manuscript published in :

Postharvest Biology and Technology (2013), Vol. 86, p. 29-36, DOI: 10.1016/j.postharvbio.2013.06.011

Journal homepage: www.elsevier.com/locate/postharvbio

\section{Results and discussion}

\subsection{Effects of pl on microbial decontamination}

Total aerobic mesophilic bacteria and total yeast and mould counts of PL-treated and untreated whole tomatoes were controlled at day $0,3,7$ and 15 of storage (Fig. 1). PL treatments caused a significant reduction in the initial microbial counts. Whole tomatoes processed by 2 pulses $\left(5.36 \mathrm{~J} / \mathrm{cm}^{2}\right)$ exhibited the lowest counts $\left(2.9 \log _{10} \mathrm{CFU} / \mathrm{g}\right)$ of aerobic mesophlic bacteria. The application of 1 or 2 pulses had the same effect $(p>0.05)$ on mould and yeast counts, with the same total counts of $1.9 \log _{10} \mathrm{CFU} / \mathrm{g}$. These results are in the same range as those of Luksiene et al. (2012), who evaluated antibacterial efficiency of PL in tomatoes by applying fluences of $5.4 \mathrm{~J} / \mathrm{cm}^{2}$. A higher microbial proliferation was observed in untreated samples than in those PL-treated during the first week of storage. However, no statistical differences among total counts of PL-treated and untreated tomatoes were found at day 15 of storage (Fig. 1). PL irradiation of fresh-cut products such as apples and mushrooms with fluences ranging from $2.4 \mathrm{~J} / \mathrm{cm}^{2}$ to $119.4 \mathrm{~J} / \mathrm{cm}^{2}$ has been reported to be effective in reducing initial microbial load and extending their microbiological shelf life by 2-3 days (Oms-Oliu et al., 2010; Gómez et al., 2012). However, Oms-Oliu et al. (2010) and Gómez et al. (2012) reported no advantage from increasing PL fluences up to the maximum applied levels because no additional inactivation would be achieved, and there is a risk that samples deteriorate as a result of the treatment.

From a micro-scale point of view, the tomato surface is full of irregularities with pores that could offer a protective place for microorganisms; in the peduncle scar these irregularities are actually visible at the macroscopic scale (Allen et al., 2005). Therefore, the disinfecting range of PL on the natural microflora present on both skin surface area and peduncle scar parts of the tomato was evaluated under treatment conditions of $1,2,3$ and $4 \mathrm{~J} / \mathrm{cm}^{2}$ using the lab-scale PL unit (Fig. 2). The application of $4 \mathrm{~J} / \mathrm{cm}^{2}$ induced maximum reductions up to 0.9 and $1.0 \log _{10}$ units of the total aerobic mesophilic bacteria when treating the epidermis and the peduncle scar, respectively. In general, results show that the higher the pulse fluence, the greater the microbial reduction. However, no significant difference (at $p>0.05$ ) was found between the microbial reductions achieved in epidermis and peduncle scar zones. Luksiene et al. (2012) reported inactivations between 1.0 and $1.3 \log _{10}$ units of naturally distributed mesophilic bacteria in

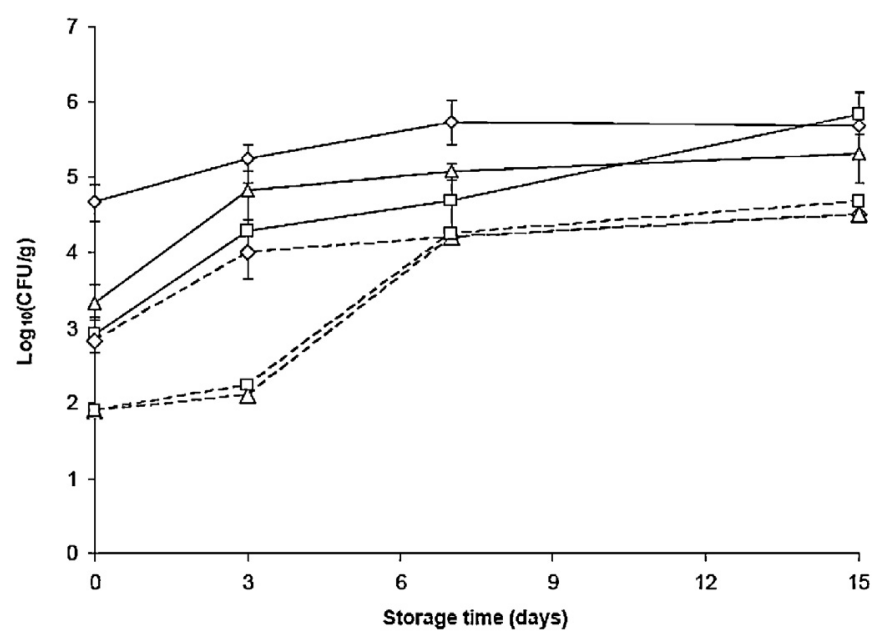

Fig. 1. Changes in counts of total aerobic mesophilic bacteria (-) and total moulds and yeast (-) during the storage at $20^{\circ} \mathrm{C}$ of PL-treated and untreated whole tomatoes. Symbols in the graph correspond to: $\diamond=$ untreated; $\Delta=1$ pulse $\left(2.68 \mathrm{~J} / \mathrm{cm}^{2}\right)$; $\square=2$ pulses $\left(5.36 \mathrm{~J} / \mathrm{cm}^{2}\right)$. Bars represent standard error, $n=5$.

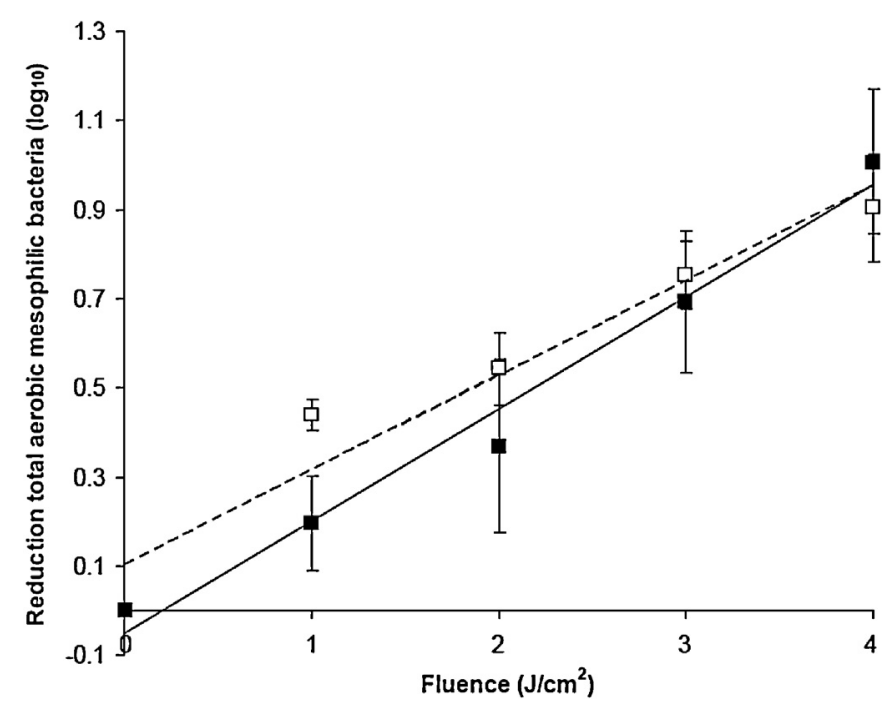

Fig. 2. Reduction of total aerobic mesophilic bacteria on tomato portions of $6.25 \mathrm{~cm}^{2}$ from the tomato peduncle scar area ( $\square$ ) and from another skin surface area ( $\square$ ) of as a function of fluence $\left(\mathrm{J} / \mathrm{cm}^{2}\right)$. The straight lines represent the regression curve on each treated area with $R^{2}=0.9812$ for peduncle scar area $(-)$ and $R^{2}=0.9399$ for skin surface area (-). Bars represent standard error, $n=9$.

different fruit and vegetables such as plums, cauliflowers, sweet peppers and strawberries, thus indicating the feasibility of PL to reduce contamination in food products with surface irregularities.

The antimicrobial PL efficiency on tomato surfaces inoculated with $S$. cerevisiae was evaluated by applying fluences of $0.3,0.56$, $0.71,1.1,1.65$ and $2.2 \mathrm{~J} / \mathrm{cm}^{2}$ delivered by the lab-scale equipment (Fig. 3). Populations of $S$. cerevisiae inoculated on tomato portions were greatly reduced when PL treatment was applied. Maximum reductions of $2.3 \log _{10}$ of $S$. cerevisiae were achieved in PL-treated tomato samples at $2.2 \mathrm{~J} / \mathrm{cm}^{2}$. This microorganism was greatly reduced by increasing PL fluence of the treatment. However, as indicated in Fig. 3, the penetration level of the microorganisms in tomato tissue microcracks and natural openings likely influences the inactivation patterns, leading to nonlinear inactivation curve with tailing, indicating that the inoculated population may be partly

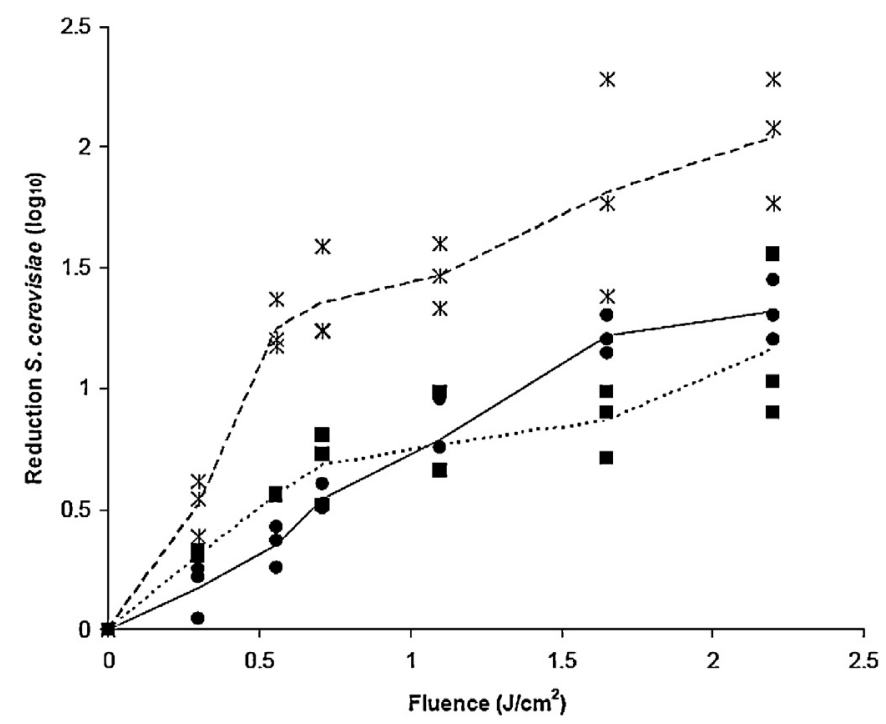

Fig. 3. Reduction of $S$. cerevisiae inoculated by spot at concentrations of around $10^{3}-10^{4} \mathrm{cfu}$ per inoculation spot on tomato portions as a function of fluence (in $\mathrm{J} / \mathrm{cm}^{2}$ ) emitted by lab-scale PL unit. Spots covered the tomato surface. Experiments were performed on lots of tomato sampled at three dates of harvest ( $\square$, and ${ }^{*}$ ). Inoculation on each tomato lot was performed on triplicate. 
Version définitive du manuscrit publiée dans / Final version of the manuscript published in :

Postharvest Biology and Technology (2013), Vol. 86, p. 29-36, DOI: 10.1016/j.postharvbio.2013.06.011

Journal homepage: www.elsevier.com/locate/postharvbio
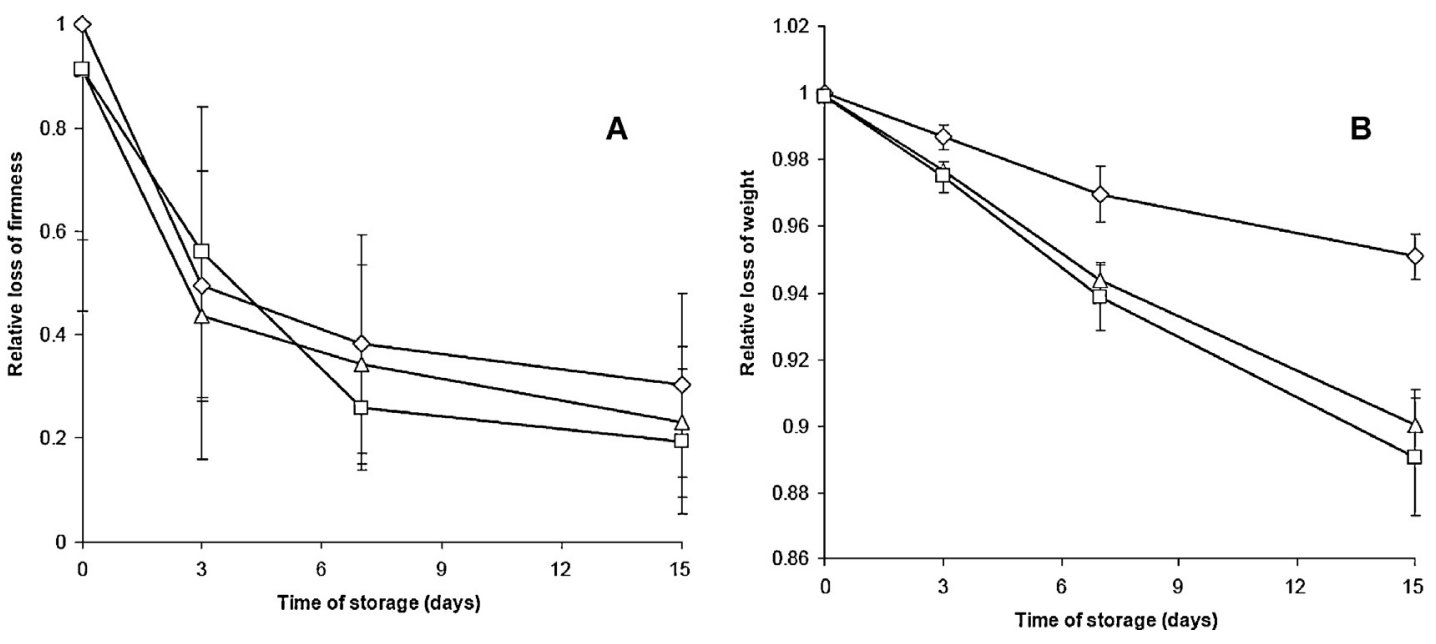

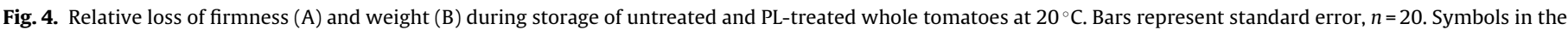
graph corresponded to: $\diamond=\operatorname{control} ; \triangle=1$ pulse $\left(2.68 \mathrm{~J} / \mathrm{cm}^{2}\right) ; \square=2$ pulses $\left(5.36 \mathrm{~J} / \mathrm{cm}^{2}\right)$.

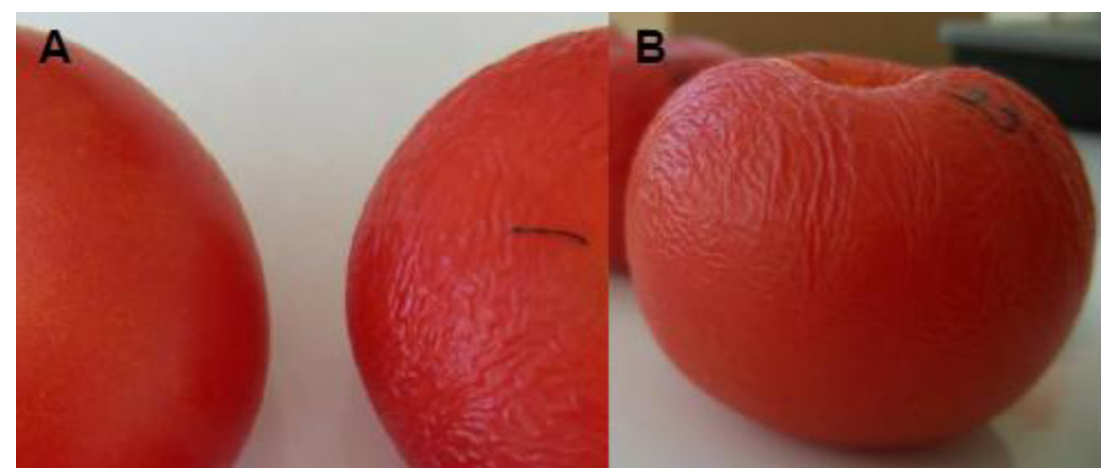

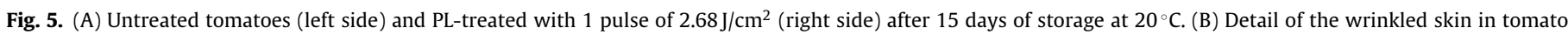
treated with 2 pulses with a total fluence of $5.36 \mathrm{~J} / \mathrm{cm}^{2}$ at day 15 of storage.

unexposed to PL. Microbial reduction levels between 2 and $1.7 \log _{10}$ have been observed in other inoculated fresh fruit treated by PL (Ramos-Villarroel et al., 2011; Gómez et al., 2012; Luksiene et al., 2012).

\subsection{Pulsed light effects on physicochemical quality}

PL treatments did not influence the colour of tomatoes (results not shown). No significant differences between untreated and PLtreated tomatoes in luminosity and hue values were observed just after treatments and during storage, as also reported by Luksiene et al. (2012) for tomatoes. PL treatments (Bialka and Demirci, 2008) also allowed maintenance of skin colour of other red fruit such as strawberry.

An appreciable loss of firmness during storage was observed in both untreated and PL-treated tomatoes (Fig. 4A). This response was correlated with a marked loss of weight (Fig. 4B). Differences in the weight between treated and untreated tomatoes began to be significant beyond 7 days of storage, but the trend was already visible after 3 days. Initial weight of untreated tomatoes was $144 \pm 11 \mathrm{~g}$, and a loss of weight of $1.3 \%$ was observed for untreated tomatoes at day 3 , and of $2.2 \%$ in both PL-treated tomatoes. A maximum percentage of $10 \%$ was recorded in twice-flashed samples at day 15 . The severe loss of weight induced by PL treatments during storage also stimulated an important physical damage on the surface of PL-treated tomatoes. Samples during storage showed a noticeable appearance of wrinkles on the surface of both PL-treated tomatoes from day 7 of storage in $100 \%$ of the samples. These visual changes were not appreciable in untreated tomatoes, which remained without physical damage throughout storage (Fig. 5). The weight loss and the skin wrinkling of PL-treated tomatoes clearly indicated a reduction of the water content in the fruit, which could be related with an increase in the respiratory rate of samples due to stress from the PL treatments. The partial dehydration resulting from the selected PL treatments may also be due to microstructure changes on the tomato surface. According to Luksiene et al. (2012), there is a concern about heat generation during pulsed light treatment. In fact, temperatures recorded on the surface of fruit immediately after exposure increased up to $15^{\circ} \mathrm{C}$ with respect to initial temperatures, without exceeding $35^{\circ} \mathrm{C}$. PL has been shown to affect the cell walls of PL-treated products during storage, but at fluences much higher than the ones used in this work. Cells from PL-treated cut apples $\left(132.7 \mathrm{~J} / \mathrm{cm}^{2}\right)$ appeared collapsed, with broken membranes and rupture and folding of cell walls after 7 days of storage (Gómez et al., 2012).

\subsection{Pulsed light effects on nutritional quality}

The ascorbic acid/dehydroascorbic acid ratio has been proposed as a marker of abiotic stress in plants (De Gara et al., 2003). Thus, ascorbic acid (AA) and its oxidised form dehydroascorbic acid (DHA) were quantified during storage of untreated and PL-treated tomatoes (Table 1). More than $80 \%$ of the total vitamin C (sum of reduced and oxidised forms) in untreated and PL-treated tomatoes was present in the reduced form. The ascorbate pool was not affected by PL treatments $(p>0.05)$ despite the clear response of 
Version définitive du manuscrit publiée dans / Final version of the manuscript published in :

Postharvest Biology and Technology (2013), Vol. 86, p. 29-36, DOI: 10.101.j/.postharvbio.2013.06.011

Journal homepage: www.elsevier.com/locate/postharvbio

Table 1

Concentrations of ascorbic acid (AA) and dehydroascorbic acid (DHA) in untreated and PL-treated tomatoes (Lycopersicum esculentum L. type "bunch", var Climberley) stored for 15 days at $20^{\circ} \mathrm{C}$.

\begin{tabular}{|c|c|c|c|c|}
\hline \multirow[t]{2}{*}{ Time of storage } & & \multicolumn{3}{|c|}{ Treatment } \\
\hline & & Control & 1 pulse & 2 pulse \\
\hline \multicolumn{5}{|c|}{ AA (mg/100 g fwt) } \\
\hline \multirow[t]{2}{*}{0} & Mean & 20 & 17 & 19 \\
\hline & Pooled SD & 6 & 3 & 1 \\
\hline \multirow[t]{2}{*}{3} & Mean & 18 & 20 & 21 \\
\hline & Pooled SD & 2 & 2 & 2 \\
\hline \multirow[t]{2}{*}{7} & Mean & 19 & 21 & 21 \\
\hline & Pooled SD & 3 & 3 & 4 \\
\hline \multirow[t]{2}{*}{15} & Mean & 21 & 20 & 24 \\
\hline & Pooled SD & 4 & 3 & 4 \\
\hline \multicolumn{5}{|c|}{ DHA (mg/100 g fwt) } \\
\hline \multirow[t]{2}{*}{0} & Mean & 0.85 & 0.89 & 0.92 \\
\hline & Pooled SD & 0.13 & 0.05 & 0.04 \\
\hline \multirow[t]{2}{*}{3} & Mean & 1.00 & 0.94 & 0.98 \\
\hline & Pooled SD & 0.12 & 0.09 & 0.12 \\
\hline \multirow[t]{2}{*}{7} & Mean & 0.99 & 1.01 & 0.98 \\
\hline & Pooled SD & 0.12 & 0.30 & 0.12 \\
\hline \multirow[t]{2}{*}{15} & Mean & 0.95 & 1.10 & 0.97 \\
\hline & Pooled SD & 0.16 & 0.23 & 0.24 \\
\hline
\end{tabular}

Mean values from the table represent the average of the means obtained from 3 analytical replicates of two lots of tomato. Pooled standard deviations (pooled SD) were calculated from the two experiments as it can be assumed that all the series are of the same precision with a percent standard deviation per analytical replicate $<10 \%$. fwt: fresh weight tomato.

the fruit. These results are in accordance to Luksiene et al. (2012) and Charles et al. (2013) who observed that PL did not affect the ascorbic acid content neither in tomatoes nor in other fruit such as strawberries and fresh-cut mangoes.

The total lycopene, $\alpha$-carotene and $\beta$-carotene content was measured in both tissue and chromoplast fractions extracted from PL-treated tomatoes plugs subjected to fluences ranging from $0 \mathrm{~J} / \mathrm{cm}^{2}$ to $30 \mathrm{~J} / \mathrm{cm}^{2}$ (Table 2). The low concentration of carotenoids in the chromoplast preparation was due to dilution of the chromoplast by the high amounts of aqueous phase used in their isolation. PL processing affected the carotenoid content of tomato tissue $(p<0.05)$ only for fluences of $30 \mathrm{~J} / \mathrm{cm}^{2}$, with significant increase in lycopene, $\alpha$-carotene and $\beta$-carotene levels. Recent studies have reported a positive influence of UV-C and UV-B irradiation on the carotenoid content of tomato. Bravo et al. (2012) observed an enhancement in lycopene and $\beta$-carotene synthesis by the postharvest treatment of mature breaker tomatoes with UV-C light. Castagna et al. (2013) also observed that postharvest UV-B irradiation increased lycopene and $\beta$-carotene concentrations in the peel of ripened tomatoes. According to Bravo et al. (2012), this is due to lycopene synthesis in the chloroplast during the off-vine ripening process. Lycopene accumulation in the tomato pericarp consists of both light-independent and light-dependent components. The pathway may be stimulated by the intensity of the PL treatment. Moreover, stimulation of carotenoid accumulation could be a photoprotective antioxidant defence response to oxidative stress caused by high PL dose (Solovchenko and Merzlyak, 2008). Rodov et al. (2012) reported similar mechanisms for anthocyanins in PL-treated figs. They observed an increment in the anthocyanin content of the skin of the fruit exposed to 90-300 s PL up to 20 times higher than untreated control, suggesting that PL might stimulate higher production of photoprotective anthocyanins under stressful conditions.

Lycopene is present in fresh tomato fruit essentially in the all-trans configuration. The main causes of tomato lycopene degradation during processing are isomerisation and oxidation. Isomerisation converts all-trans isomers to cis-isomers due to additional energy input and results in an unstable, energy-rich station (Shi and Le Maguer, 2000). Cis-isomers were present in all the samples, particularly 13-cis and 15-cis-lycopene, were the major cis forms (data not shown). However, all-trans-lycopene was the main isomer. Percentages of cis-isomers remained unchanged around $12 \%$ in all the chromoplast fractions obtained from PL-treated tomatoes (Fig. 6). In contrast, a significant increase in the percentage of isomerisation (up to $16 \%$ ) in tissue fractions was observed when tomato plugs were treated at fluences higher than $20 \mathrm{~J} / \mathrm{cm}^{2}$. This minor change indicated good lycopene stability to PL processing. PL processing at high fluences was not detrimental from a nutritional point of view, as the carotenoid profile was not degraded and vitamin $C$ concentrations were not modified in tomato.

Accessibility of the lycopene, i.e. its release from the food matrix to the lipophilic phase of the food emulsion in the gastric environment, was evaluated. The composition and structure of the food have an impact on the bio-availability of lycopene especially depending whether the matrix is cooked or not. Table 3 shows the concentrations of total lycopene and percentage of accessible total lycopene in fresh and hot break purees obtained from untreated and PL-treated whole tomatoes. The application of PL

Table 2

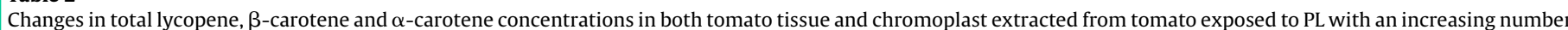
of pulses.

\begin{tabular}{|c|c|c|c|c|c|c|c|c|c|}
\hline \multirow[t]{2}{*}{ Tomato fractions } & & \multicolumn{8}{|c|}{ Number of pulses } \\
\hline & & 0 & 1 & 8 & 12 & 18 & 20 & 24 & 30 \\
\hline \multicolumn{10}{|l|}{ Tissue } \\
\hline \multirow[t]{2}{*}{ Total lycopene (mg/kg fwt) } & Mean & $5.4 \mathrm{a}$ & $4.9 \mathrm{a}$ & $4.7 \mathrm{a}$ & $4.8 \mathrm{a}$ & $4.9 \mathrm{a}$ & $4.8 \mathrm{a}$ & $4.7 \mathrm{a}$ & $7.9 \mathrm{~b}$ \\
\hline & Pooled SD & 0.1 & 0.7 & 0.4 & 0.3 & 0.2 & 0.1 & 0.7 & 0.1 \\
\hline \multirow[t]{2}{*}{$\beta$-Carotene $(\mu \mathrm{g} / \mathrm{kg}$ fwt $)$} & Mean & $465 b$ & $358 a$ & $365 a b$ & $468 b$ & $389 a b$ & $373 a b$ & $427 \mathrm{ab}$ & $713 c$ \\
\hline & Pooled SD & 31 & 32 & 36 & 29 & 6 & 50 & 90 & 20 \\
\hline \multirow[t]{2}{*}{$\alpha$-Carotene $(\mu \mathrm{g} / \mathrm{kg}$ fwt $)$} & Mean & $55 c$ & $56 c$ & $51 \mathrm{bc}$ & $41 \mathrm{ab}$ & $39 \mathrm{ab}$ & $36 a$ & $41 \mathrm{abc}$ & $60 c$ \\
\hline & Pooled SD & 4 & 5 & 2 & 2 & 12 & 10 & 10 & 0.8 \\
\hline \multicolumn{10}{|l|}{ Chromoplast } \\
\hline \multirow{2}{*}{ Total lycopene (mg/kg fwt) } & Mean & $974 a$ & $914 a$ & $809 a$ & $921 a$ & $844 a$ & $869 a$ & $883 a$ & $1008 b$ \\
\hline & Pooled SD & 126 & 36 & 21 & 34 & 58 & 70 & 30 & 8 \\
\hline \multirow[t]{2}{*}{$\beta$-Carotene $(\mu \mathrm{g} / \mathrm{kg}$ fwt $)$} & Mean & $89 a$ & $83 a$ & $73 a$ & $82 a$ & $75 a$ & $76 a$ & $76 a$ & $85 a$ \\
\hline & Pooled SD & 11 & 3 & 2 & 2 & 5 & 9 & 9 & 0.4 \\
\hline \multirow[t]{2}{*}{$\alpha$-Carotene $(\mu \mathrm{g} / \mathrm{kg}$ fwt $)$} & Mean & $4.7 \mathrm{a}$ & $4.2 \mathrm{a}$ & $3.7 \mathrm{a}$ & $4.4 \mathrm{a}$ & $3.8 \mathrm{a}$ & $3.9 \mathrm{a}$ & $3.8 \mathrm{a}$ & $4.2 \mathrm{a}$ \\
\hline & Pooled SD & 0.2 & 0.2 & 0.1 & 0.1 & 0.3 & 0.3 & 0.1 & 0.1 \\
\hline
\end{tabular}


Version définitive du manuscrit publiée dans / Final version of the manuscript published in :

Postharvest Biology and Technology (2013), Vol. 86, p. 29-36, DOI: 10.1016/,j.postharvbio.2013.06.011

Journal homepage: www.elsevier.com/locate/postharvbio

Table 3

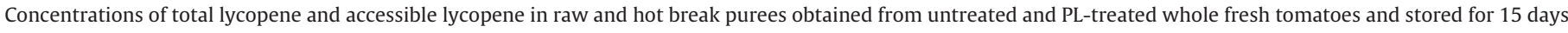
at $20^{\circ} \mathrm{C}$.

\begin{tabular}{|c|c|c|c|c|c|c|c|}
\hline \multirow[t]{3}{*}{ Time of storage } & & \multicolumn{6}{|c|}{ Treatments } \\
\hline & & \multicolumn{2}{|l|}{ Control } & \multicolumn{2}{|l|}{1 pulse } & \multicolumn{2}{|c|}{2 pulses } \\
\hline & & Raw & Hot break & Raw & Hot break & Raw & Hot break \\
\hline \multicolumn{8}{|c|}{ Lycopene (mg/kg tomato puree) } \\
\hline \multirow[t]{2}{*}{0} & Mean & 76Bab & $91 \mathrm{Ea}$ & $67 \mathrm{Aa}$ & $70 A a$ & $81 \mathrm{BCb}$ & 87Db \\
\hline & Pooled SD & 9 & 45 & 6 & 1 & 2 & 9 \\
\hline \multirow[t]{2}{*}{3} & Mean & $67 \mathrm{Aa}$ & 80Aba & $91 \mathrm{ABc}$ & $93 \mathrm{ABb}$ & $95 \mathrm{ABc}$ & $112 \mathrm{Cc}$ \\
\hline & Pooled SD & 5 & 26 & 5 & 1 & 6 & 26 \\
\hline \multirow[t]{2}{*}{7} & Mean & $91 \mathrm{ABb}$ & 94Aba & 82Aab & $102 \mathrm{Bb}$ & $86 \mathrm{ABb}$ & $92 \mathrm{ABb}$ \\
\hline & Pooled SD & 10 & 19 & 7 & 15 & 5 & 7 \\
\hline \multirow[t]{2}{*}{15} & Mean & 81Bab & 92BCa & 83Bab & $98 \mathrm{Cb}$ & $74 \mathrm{Aa}$ & $72 \mathrm{Aa}$ \\
\hline & Pooled SD & 8 & 68 & 6 & 5 & 9 & 10 \\
\hline \multicolumn{8}{|c|}{ Accessible lycopene (\% of total lycopene) } \\
\hline \multirow[t]{2}{*}{0} & Mean & $24 \mathrm{Aa}$ & $30 A a$ & $23 \mathrm{Aa}$ & $34 \mathrm{Aa}$ & $23 \mathrm{Aa}$ & $28 \mathrm{Aa}$ \\
\hline & Pooled SD & 4 & 1.0 & 6 & 1 & 2 & 9 \\
\hline \multirow[t]{2}{*}{3} & Mean & $26 A a$ & 30Aa & $17 \mathrm{Aa}$ & 36Aa & $21 \mathrm{Aa}$ & $28 \mathrm{Aa}$ \\
\hline & Pooled SD & 5 & 0.1 & 1 & 1 & 5 & 1 \\
\hline \multirow[t]{2}{*}{7} & Mean & $21 \mathrm{Aa}$ & $27 \mathrm{Aa}$ & $21 \mathrm{Aa}$ & $28 \mathrm{Aa}$ & $23 \mathrm{Aa}$ & $24 \mathrm{Aa}$ \\
\hline & Pooled SD & 1 & 0.2 & 6 & 5 & 5 & 6 \\
\hline \multirow[t]{2}{*}{15} & Mean & $35 \mathrm{Ab}$ & $36 \mathrm{Ab}$ & $31 \mathrm{Ab}$ & 33Aa & $33 \mathrm{Ab}$ & $41 \mathrm{Ab}$ \\
\hline & Pooled SD & 8 & 2.2 & 6 & 5 & 9 & 1 \\
\hline
\end{tabular}

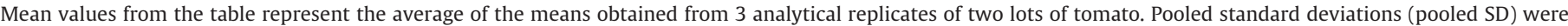

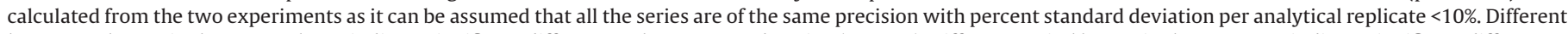

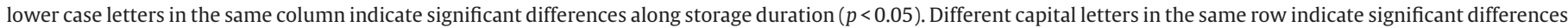
among PL treatments $(p<0.05)$.

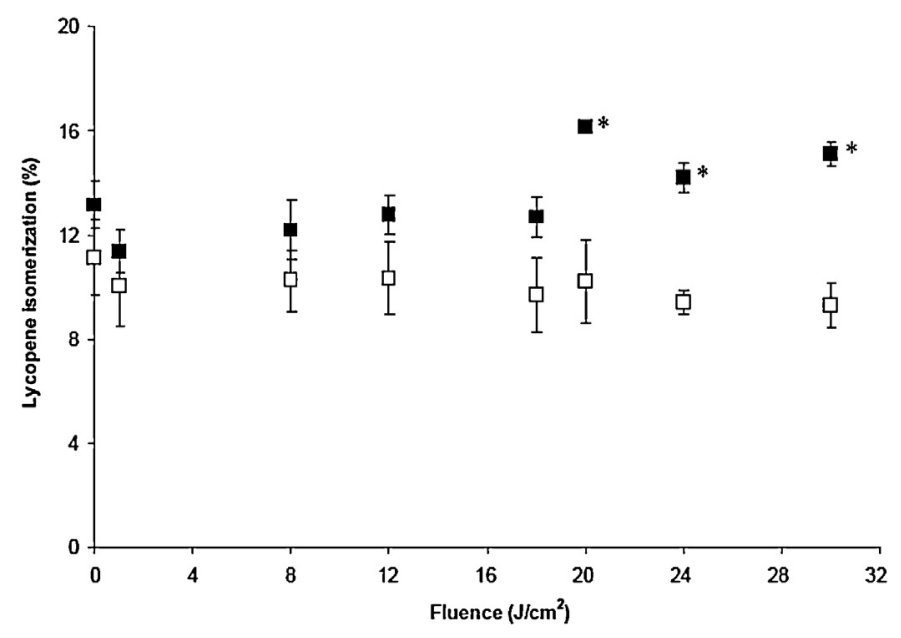

Fig. 6. Percentage of lycopene isomerisation obtained in both tomato tissue ( $\square$ and chromoplast $(\square)$ extracted from fresh tomato fruit (Lycopersicum esculentum $\mathrm{L}$. type "bunch", var Climberley) subjected to different PL treatment conditions. One pulse corresponds to a fluence of $1 \mathrm{~J} / \mathrm{cm}^{2}$. Bars represent standard error, $n=3$. Significant differences in lycopene isomerisation \% were determined using Student's $t$-test ${ }^{*} p<0.05$.

processing to whole tomatoes had limited impact on the initial content of lycopene in the purees. Raw and hot break purees obtained from whole tomatoes treated with one pulse had the lowest total lycopene contents (Table 3). Moreover, hot break purees from all the samples showed higher total lycopene content than raw purees during storage. Small but significant variations in the initial lycopene concentrations of raw and cooked purees were observed during the 15 days. According to Gartner et al. (1997) the lycopene bio-availability of tomatoes is enhanced when they are heated. On the other hand, percentage of accessible lycopene represents the proportion of total lycopene that can be made accessible by the digestive process. Percentages of accessible lycopene of roughly 22 and 33\% were observed in raw and hot break purees, respectively, irrespective of the PL treatment applied (Table 3). The most outstanding results were obtained at day 15 in all the samples with a significant increase in the accessible lycopene. Particularly, hot break purees obtained from whole PL-treated tomatoes with 2 pulses showed the highest percentage (41.3\%) indicating that more lycopene could be bio-accessible by the end of the storage.

\section{Conclusion}

Pulsed light was able to reduce by about $1 \log _{10}$ natural and inoculated microbial contamination on tomato fruit. However, no statistical differences among total counts of PL-treated and untreated tomatoes were found at day 15 of storage. Pulsed light did not lead to loss of nutritional quality, as vitamin $C$ was unaffected while carotenoid concentrations were actually slightly increased. However, pulsed light severely reduced acceptability product quality by causing an important weight loss and visible wrinkles from day 3.

\section{Acknowledgements}

This work was supported by the Ministerio de Ciencia y Tecnología (Spain) through the Project AGL 2006-04775. I. AguilóAguayo thanks the Ministerio de Educación y Ciencia (Spain) for the awarded grant. Authors would like to thank the Claranor SA company (Avignon, France) which provided the pulsed light equipment.

\section{References}

Ait Barka, E., Kalantari, S., Makhlouf, J., Arul, J., 2000. Impact of UV-C irradiation on the cell wall-degrading enzymes during ripening of tomato (Lycopersicon esculentum L) fruit. J. Agric. Food Chem. 48, 667-671.

Allen, R.L., Warren, B.R., Archer, D.L., Sargent, S.A., Schneider, K.R., 2005. Survival of Salmonella spp. on the surfaces of fresh tomatoes and selected packing line materials. HortTechnology 15, 831-836.

Bialka, K.L., Demirci, A., 2008. Efficacy of pulsed UV-light for the decontamination of Escherichia coli 0157:H7 and Salmonella spp on raspberries and strawberries. J. Food Sci. 73, M201-M207.

Bravo, S., García-Alonso, J., Martín-Pozuelo, G., Gómez, V., Santaella, M., NavarroGonzález, I., Periago, M.J., 2012. The influence of post-harvest UV-C hormesis on 


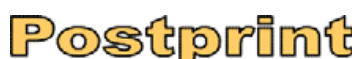

\section{Version définitive du manuscrit publiée dans / Final version of the manuscript published in : \\ Postharvest Biology and Technology (2013), Vol. 86, p. 29-36, DOI: 10.1016/j.postharvbio.2013.06.011 \\ Journal homepage: www.elsevier.com/locate/postharvbio}

lycopene, $\beta$-carotene, and phenolic content and antioxidant activity of breaker tomatoes. J. Food Res. Int. 49, 296-302.

Castagna, A., Chiavaro, E., Dall'Asta, C., Rinaldi, M., Galaverna, G., Ranieri, A., 2013. Effect of postharvest UV-B irradiation on nutraceutical quality and physical properties of tomato fruits. Food Chem. 137, 151-158.

Charles, M.T., Makhlouf, J., Arul, J., 2008. Physiological basis of UV-C induced resistance to Botrytis cinerea in tomato fruit II. Modification of fruit surface and changes in fungal colonization. Postharvest Biol. Technol. 47, 21-26.

Charles, F., Vidal, V., Olive, F., Filgueiras, H., Sallanon, H., 2013. Pulsed light treatment as new method to maintain physical and nutritional quality of fresh-cut mangoes. Innov. Food Sci. Emerg., http://dx.doi.org/10.1016/j.ifset.2013.02.004.

Clinton, S.K., 1998. Lycopene: chemistry, biology, and implications for human disease. Nutr. Rev. 56, 35-51.

De Gara, L., de Pinto, M.C., Moliterni, V.M., D’Egidio, M.G., 2003. Redox regulation and storage processes during maturation in kernels of Triticum durum. J. Exp. Bot. 54, 249-258.

Degrou, A., Georgé, S., Renard, C.M.G.C., Page, D., 2013. Physicochemical parameters that influence carotenoids bioaccessibility from a tomato juice. Food Chem. 136, 435-441.

Elmnasser, N., Ritz, M., Leroid, F., Orange, N., Bakhrouf, A., Federighi, M., 2007. Bacterial inactivation using pulsed light. Acta Aliment. 35, 401-408.

Gartner, C., Stahl, W., Sies, H., 1997. Lycopene is more bioavailable from tomato paste than from fresh tomatoes. Am. J. Clin. Nutr. 66, 116-122.

Giovanelli, G., Lavelli, V., Peri, C., Nobili, S., 1999. Variation in antioxidant components of tomato during vine and post-harvest ripening. J. Sci. Food Agric. 79, 1583-1588

Gómez, P.L., Salvatori, D.M., García-Loredo, A., Alzamora, S.M., 2012. Pulsed light treatment of cut apple: dose effect on colour, structure and microbiological stability. Food Bioprocess Technol. 5, 2311-2322.

Grotte, M., Duprat, F., Loonis, D., Piétri, E., 2001. Mechanical properties of the skin and the flesh of apples. Int. J. Food Prop. 4, 149-161.

Heredia, A., Peinado, I., Barrera, C., Grau, A.A., 2009. Influence of process variables on colour changes, carotenoids retention and cellular tissue alteration of cherry tomato during osmotic dehydration. J. Food Compost. Anal. 22, 285-294.

Jagadeesh, K.S., Jagadeesh, D.R., 2009. Biological control of early blight of tomato caused by Alternaria solani as influenced by different delivery methods of Pseudomonas gladioli B25. Acta Hortic. 808, 327-332.

Kalaras, M.K., Beelman, R.B., Elias, R.J., 2012. Effects of postharvest pulsed UV light treatment of white button mushrooms (Agaricus bisporus) on vitamin D2 content and quality attributes. J. Agric. Food Chem. 60, 220-225.
Liu, L.H., Zabaras, D., Bennett, L.E., Aguas, P., Woonton, B.W., 2009. Effects of UV$\mathrm{C}$, red light and sun light on the carotenoid content and physical qualities of tomatoes during post-harvest storage. Food Chem. 115, 495-500.

Luksiene, Z., Buchovec, I., Kairyte, K., Paskeviciute, E., Viskelis, P., 2012. High-powe pulsed light for microbial decontamination of some fruits and vegetables with different surfaces. J. Food Agric. Environ. 10, 162-167.

Maharaj, R., Arul, J., Nadeau, P., 1999. Effect of photochemical treatment in the preservation of fresh tomato (Lycopersicon esculentum cv. Capello) by delaying senescence. Postharvest Biol. Technol. 15, 13-23.

McNaught, A.D., Wilkinson, A., 1997. Compendium of Chemical Terminology: The Gold Book, 2nd ed. Blackwell Science, Indiana.

Oms-Oliu, G., Aguiló-Aguayo, I., Martín-Belloso, O., Soliva-Fortuny, R., 2010. Effects of pulsed light treatments on quality and antioxidant properties of fresh-cut mushrooms (Agaricus bisporus). Postharvest Biol. Technol. 56, 216-222.

Page, D., Van Stratum, E., Degrou, A., Renard, C.M.G.C., 2012. Kinetics of temperature increase during tomato processing modulate the bioaccessibility of lycopene. Food Chem. 135, 2462-2469.

Ramos-Villarroel, A.Y., Martín-Belloso, O., Soliva-Fortuny, R., 2011. Bacterial inactivation and quality changes in fresh-cut avocado treated with intense light pulses. Eur. Food Res. Technol. 233, 395-402.

Ramos-Villarroel, A.Y., Aron-Maftei, N., Martín-Belloso, O., Soliva-Fortuny, R., 2012. Influence of spectral distribution on bacterial inactivation and quality changes of fresh-cut watermelon treated with intense light pulses. Postharvest Biol. Technol. 69, 32-39.

Rao, A.V., Agarwal, S., 2000. Role of antioxidant lycopene in cancer and heart disease. J. Am. Coll. Nutr. 19, 563-569.

Rodov, V., Vinokur, Y., Horev, B., 2012. Brief postharvest exposure to pulsed light stimulates coloration and anthocyanin accumulation in fig fruits (Ficus carica L). Postharvest Biol. Technol. 68, 43-46.

Shi, J., Le Maguer, M., 2000. Lycopene in tomatoes: chemical and physical properties affected by food processing. Crit. Rev. Food Sci. Nutr. 40, 1-42.

Solovchenko, A.E., Merzlyak, M.N., 2008. Screening of visible and UV radiation as a photoprotective mechanism in plants. Russ. J. Plant Physiol. 55, 719-737.

Stevens, R., Page, D., Gouble, B., Garchery, C., Zamir, D., Causse, M., 2008. Tomato fruit ascorbic acid content is linked with monodehydroascorbate reductase activity and tolerance to chilling stress. Plant Cell Environ. 31, 1086-1096.

Takeshita, K., Shibato, J., Sameshima, T., Fukunaga, S., Isobe, S., Arihara, K., Itoh, M., 2003. Damage of yeast cells induced by pulsed light irradiation. Int. J. Food Microbiol. 85, 151-158.

Wekhof, A., 2000. Disinfection with flash lamps. PDA J. Pharm. Sci. Technol. 54, 264-276. 